\title{
A dust event in the Mongolian Gobi Desert in spring 2016: Observations and vertical dust flux estimation
}

\author{
Dulam Jugder ${ }^{1, *}$ \\ ${ }^{1}$ Information and Research Institute of Meteorology, Hydrology and Environment, Ulaanbaatar 15160, Mongolia
}

\begin{abstract}
A meteorological and dust monitoring tower with $20 \mathrm{~m}$ height set up at a Nomgon site in the Mongolian Gobi Deserts in 2010. The Nomgon monitoring tower equipped with wind speed sensors at 2, 4, 10 and $20 \mathrm{~m}$ height above the ground level (AGL), a wind direction sensor at $10 \mathrm{~m}$ height, a sonic anemometer to measure turbulent momentum flux at $8 \mathrm{~m}$ height and a soil moisture sensor at $5 \mathrm{~cm}$ depth. A dust storm was expected in the Mongolian Gobi from 30 April to 1 May 2016 and two aerosol monitors (Dust-Trak) were set at 0.9 and $2.95 \mathrm{~m}$ heights in the tower for measuring $\mathrm{PM}_{10}$. Above mentioned data from the tower during an intensive observation period (IOP) of the dust event are used in this study. In association with a surface cyclone, its frontal system and a trough aloft, dust concentrations of $\mathrm{PM}_{10}$ increased during the dust storm period due to raised wind speed in the dry conditions of air and soil. The present study aims to estimate friction velocity $\left(u_{*}\right)$ and vertical dust flux $(F)$ around the Nomgon site during the dust storm period. The observations and estimation results are presented.
\end{abstract}

\section{Introduction}

Large amount of dust aerosol lifts up in the air due to windblown dust emission and severe dust storm events $[1,2,3]$. Severe dust storm events make threats to human lives and cause considerable economic damages $[4,5,6]$. High concentrations of particles with diameters of less than 10 micrometers $\left(\mathrm{PM}_{10}\right)$ can result in negative impacts on human respiratory health [7]. Fine dust particles with sizes smaller than $20 \mu \mathrm{m}$ suspended in the atmosphere can be transported faraway from source region and be deposited in downwind areas $[8,9,10]$.

Windblown dust occurs where soil particles move by wind force. This process involves the dust cycle in the atmosphere. The dust cycle consists of three major physical mechanisms such as dust emission, transport and deposition $[6,11]$. Dust emission takes place only for wind $(U)$ and friction velocities $u_{*}$ ) higher than their threshold values $\mathrm{U}>\mathrm{U}_{\mathrm{t}}$ and $\mathrm{u}_{*}>\mathrm{u}_{* \mathrm{t}}$ ) [12]. As $u_{*}$ is one of the most important parameters in dust emission studies [6]. $u_{*}$ is not the speed of the flow but it is a descriptor of turbulence intensity (or friction) in the surface layer [6]. Friction velocity is governed by the apparent roughness of the surface and atmospheric convection or stability $[13,14]$. Turbulent motion, wind speed $(U)$, friction velocities $\left(u_{*}\right)$ play a main role in parameterizations of dust emission in models $[15,16,17$, $18,19]$.

Gradient measurements of wind speeds and turbulent momentum flux at the meteorological and dust monitoring tower with 20-m height at the Nomgon site in the desert steppe (Gobi) area of Mongolia are a main data of this study. In addition, we aim to measure $\mathrm{PM}_{10}$ dust concentrations at two levels during an intensive observation period (IOP) of a dust storm. Based on these measurements, friction velocity $\left(u_{*}\right)$ and vertical dust emission flux around the Nomgon site are attempted to be estimated during the dust storm period.

\section{Used data}

\subsection{Meteorological data}

A meteorological and dust monitoring tower with a height of $20 \mathrm{~m}$ was established at the Nomgon site $\left(42^{\circ} 50^{\prime} 27.26^{\prime \prime} \mathrm{N}, 105^{\circ} 7^{\prime} 52.53^{\prime \prime} \mathrm{E}\right)$ in 2010 (Fig. 1). The tower gradient measurement data including air temperature and relative humidity at $2 \mathrm{~m}$ level, wind speeds at 2, 4 and $10 \mathrm{~m}$ levels and wind components $(u, v, w)$ by a sonic anemometer at $8 \mathrm{~m}$ level, soil moisture $5 \mathrm{~cm}$ depth were used in this study (Table 1).

\footnotetext{
*Corresponding author: jugder12@gmail.com
} 
The sonic anemometer measures turbulent momentum and sensible heat fluxes.

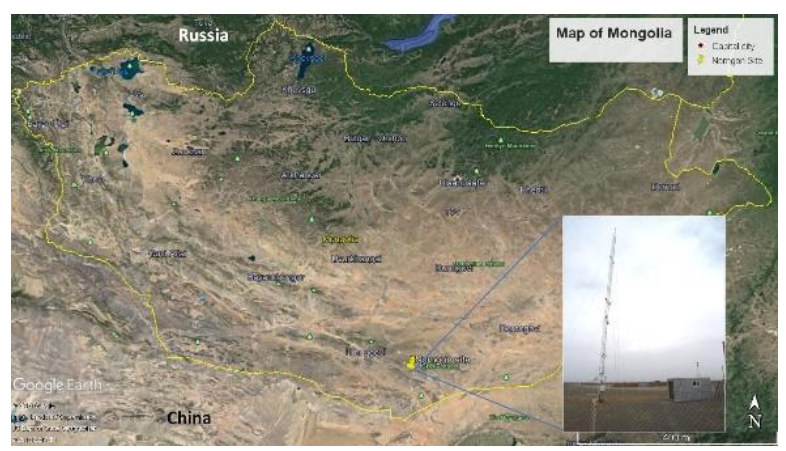

Figure 1. Location of the Nomgon site in the southern Gobi Desert region, Mongolia and the tower.

Table 1. Instruments and measurements at the tower of the Nomgon site.

\begin{tabular}{|c|c|c|c|}
\hline Data type & $\begin{array}{c}\text { Instrument } \\
\text { model, producer }\end{array}$ & $\begin{array}{c}\text { Measurem ent } \\
\text { ranges }\end{array}$ & $\begin{array}{c}\text { Measurem ent height, } \\
\text { depth, } \mathrm{m} \text { or cm }\end{array}$ \\
\hline Data logger & $\begin{array}{l}\text { CR3000 } \\
\text { (Campbell) }\end{array}$ & & $1.5 \mathrm{~m}$ \\
\hline $\begin{array}{l}\text { Air temperature and } \\
\text { Relative humidity }(\mathrm{RH})\end{array}$ & HMP45A (Vaisala) & $\begin{array}{l}-40-60^{\circ} \mathrm{C} \\
0.8-100 \%\end{array}$ & $2,4,8,16 \mathrm{~m}$ \\
\hline Wind speed & 03101 (Campbell) & $0-60 \mathrm{~m} \mathrm{~s}^{-1}$ & $2,4,10,16,20 \mathrm{~m}$ \\
\hline Wind direction & 03001 (Campbell) & $0-360$ degree & $10,20 \mathrm{~m}$ \\
\hline Soil depth temperature & 107 (Campbell) & $-35-50^{\circ} \mathrm{C}$ & $5,20,50 \mathrm{~cm}$ depth \\
\hline Soil moisture & CS615 (Campbell) & $0-1 \mathrm{v} / \mathrm{v}$ & $5,20,50 \mathrm{~cm}$ depth \\
\hline Air pressure & $\begin{array}{l}\text { PTB101 or } \\
\text { PTB110 (Vai sala) }\end{array}$ & $500-1100 \mathrm{hPa}$ & $2 \mathrm{~m}$ \\
\hline Precipitation & $\begin{array}{l}\text { TE } 525 \mathrm{~mm} \text { (Texas } \\
\text { Electronics) }\end{array}$ & $0.1 \mathrm{~mm}-$ inf & At the ground surface \\
\hline Turbulence flux & CSAT (Campbell) & $-30-30 \mathrm{~m} \mathrm{~s}^{-1}$ & $8 \mathrm{~m}$ \\
\hline $\begin{array}{l}\text { Dust mass } \\
\text { concentration }\left(\mathrm{PM}_{10}\right)\end{array}$ & $\begin{array}{l}\text { FH62C14 } \\
\text { (Thermo) }\end{array}$ & $0-5000 \mu \mathrm{g} \mathrm{m}^{-3}$ & $3 \mathrm{~m}$ \\
\hline
\end{tabular}

\subsection{Soil and vegetation condition around the site}

The Nomgon site area is located in the Desert steppe (Gobi) regions at the end of the Altai Mountain. The environmental land surface condition around the site is characterized by flat valley between hills, homogenous terrain with scarce vegetation.

Observations on soil and vegetation conditions are made around the Nomgon site in 30 April 2016 (Fig. 2). The site is open to north $(\mathrm{N})$ and north-west (NW) directions. We measured vegetation density in a valley from the site to $\mathrm{N}$ and NW. The measurement field is located in $3 \mathrm{~km}$ distance from the site. Vegetation density was scarce around the field and in the valley. Gravel covers the flat surface and loose fine dust is under gravel. Anabasis brevifolia was sparsely growing in the valley and average distance between roots of Anabasis brevifolia was 1-5 m.
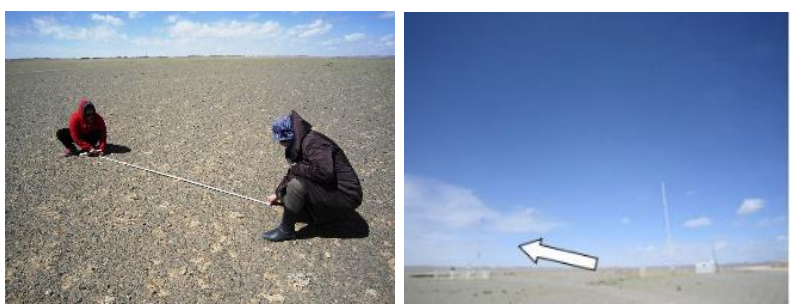

Figure 2. Photos of soil surface and vegetation conditions in $\mathrm{N}$ and NW directions from the Nomgon site.

\subsection{Field measurement data}

Before dust events, we made zero calibrations for the two instruments. For this purpose, we put two instruments at 0.9 and $2.95 \mathrm{~m}$ levels and measured $\mathrm{PM}_{10}$ concentrations, simultaneously. Statistical methods are used for data analysis.

Measurements of $\mathrm{PM}_{10}$ concentrations at 0.9 and $2.95 \mathrm{~m}$ levels were conducted over a two-day period at the Nomgon site during the dust storm period from 30 April to 1 May 2016 using two aerosol monitoring instruments (Dust Trak-8533). These $\mathrm{PM}_{10}$ data are used in this study.

\section{Methodology}

\subsection{Friction velocity $\left(u_{*}\right)$}

Friction velocity $\left(u_{*}\right)$ is expressed as:

$$
u_{*}=\sqrt[4]{{\overline{w^{\prime} u^{\prime}}}^{2}+{\overline{w^{\prime} v^{\prime}}}^{2}}
$$

where, $u_{*}$ is friction velocity $\left(\mathrm{m} \mathrm{s}^{-1}\right)$ and it is constant in the surface layer or in the constant flux layer, $u^{\prime}, v^{\prime}, w^{\prime}$ - turbulent wind speed components along $\mathrm{x}, \mathrm{y}$, $\mathrm{z}$ axis (at $8 \mathrm{~m}$ level), respectively, $\overline{u^{\prime} w^{\prime}}$ - covariance between $u^{\prime}$ and $w^{\prime}, \quad \overline{v^{\prime} w^{\prime}}$ - covariance between $v^{\prime}$ and $w^{\prime}$.

\subsection{Vertical dust flux}

Vertical dust flux for $\mathrm{PM}_{10}$ concentration can be determined using following equation $[8,9,10,15,20$, 21, 22]:

$$
F=-K_{z} \frac{d C}{d z}
$$

where, F - vertical dust flux $\left(\mathrm{mg} \mathrm{\textrm {m } ^ { - 2 }} \mathrm{s}^{-1}\right), d C-$ difference between $\mathrm{PM}_{10}$ concentrations measured at various heights $\left(\mathrm{mg} \mathrm{m}^{-3}\right), d z$ - difference between heights $(\mathrm{m}), u_{*}-$ friction velocity $\left(\mathrm{m} \mathrm{s}^{-1}\right), K_{z}-$ the vertical eddy diffusivity at $\mathrm{z}$ height $\left(\mathrm{m}^{2} \mathrm{~s}^{-1}\right)$, it is expressed as:

$$
K_{z}=\frac{k(z-d) u_{*}}{\phi_{h}}
$$

where, k - von Karman constant, it characterizes the dimensionless wind shear for statically neutral conditions. $d$ - zero plane displacement $(\mathrm{m}), \phi_{h}-$ is the non-dimensional vertical profile function for heat defined as $\phi_{h}=(1-15 z / L)^{-1 / 2}$ for the unstable stratification, $\phi_{h}=1+5 z / L$ for the stable stratification, $L-$ is the Monin-Obukhov length scale that is formulated as:

$$
L=-\frac{\bar{T} \mathbf{u}_{*}^{3}}{k g \overline{w^{\prime} T^{\prime}}}
$$


where, $\bar{T}$ is the mean air temperature $(K), g$ is the gravitational acceleration $\left(\mathrm{m} \mathrm{s}^{-2}\right)$ and $\overline{w^{\prime} T^{\prime}}$ the kinematic heat flux.

Vertical dust flux is proportional to a power function of friction velocity $[16,23]$ and it is as:

$$
F=a \cdot u_{*}^{n}
$$

where, $F$ - vertical dust flux $\left(\mathrm{mg} \mathrm{m}^{-2} \mathrm{~s}^{-1}\right), a$ is coefficient, $u_{*}$ is friction velocity $\left(\mathrm{m} \mathrm{s}^{-1}\right), n$ is the power of function, it is between 3 and 7 [23].

\section{Results}

\subsection{Data analysis}

For calibration instruments, we set up two Dust Trak at same levels $(0.9$ and $2.95 \mathrm{~m})$ in the tower, and measured concentration of $\mathrm{PM}_{1} \mathrm{PM}_{2.5} \mathrm{PM}_{4}$ and $\mathrm{PM}_{10}$ during one hour for each two levels with 1-minute interval. The Dust Trak1 (DT1) was at $0.9 \mathrm{~m}$ level, while the Dust Trak2 (DT2) was at $2.95 \mathrm{~m}$ level. A linear regression equation (Eq. 6) between $\mathrm{PM}_{10}$ concentrations at $2.95 \mathrm{~m}$ level by two DTs was found as:

$$
Y=0.6536 \cdot x+0.0036 \quad\left(R^{2}=0.917\right)
$$

where, $Y-\mathrm{PM}_{10}$ concentration values by the DT2, $x-$ $\mathrm{PM}_{10}$ concentration values by the DT1. We corrected as $\mathrm{PM}_{10}$ concentration by the DT2 at $2.95 \mathrm{~m}$ level using Eq. 6. The corrected $\mathrm{PM}_{10}$ concentration is used for next calculation.

\subsection{Meteorological characteristics and dust concentration of $\mathrm{PM}_{10}$}

The dust event occurred in 30 April to 1 May in association with low-pressure system and its atmospheric cold front passed across the Gobi Deserts including the site. There was no precipitation over the Gobi Desert region in April 2016 [24]. Moreover, measured soil moisture was $7.7-8.8 \%$ and relative humidity varied from 13.4 to $40.0 \%$ at the site during the IOP. Thus, soil and air were dry around the site before and during the dust event. The wind speed increased reaching from 11 to $17 \mathrm{~m} \mathrm{~s}^{-1}$. Visibility was around $20 \mathrm{~km}$ in the morning of 1 May.

Dust concentration of $\mathrm{PM}_{10}$ at $0.9 \mathrm{~m}$ level was 26 to $70 \mu \mathrm{g} \mathrm{m}^{-3}$ at 3:40-5:50 (Local Standard Time - LST) on 30 April and it raised to $88-338 \mu \mathrm{g} \mathrm{m}^{-3}$ at 9:10-11:30 LST on 1 May (Fig. 3).

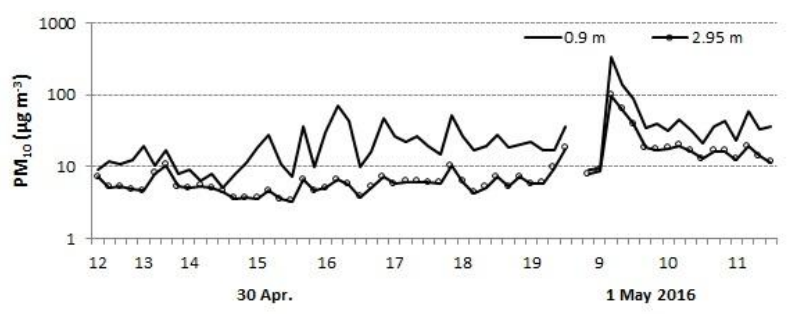

Figure 3. Dust concentration of $\mathrm{PM}_{10}$ measured at 0.9 and $2.95 \mathrm{~m}$ levels from 30 April to 1 May 2016 (Time is Local Standard Time-LST).

\subsection{Estimation of friction velocity and the vertical eddy diffusivity}

Friction velocity $\left(u_{*}\right)$ is computed using Eq. 1 that is based on turbulent wind speed components $(u, v, w)$ at $8 \mathrm{~m}$ height and their 10-min averaged covariance $\overline{\left(u^{\prime} w^{\prime}\right.}$ and $\left.\overline{v^{\prime} w^{\prime}}\right)$. Friction velocity $\left(u_{*}\right)$ varied from 0.0114 to $0.7175 \mathrm{~m} \mathrm{~s}^{-1}$ from 12:00 LST on 30 April to 08:00 LST on 1 May 2016 and rose from 0.2043 to $1.1322 \mathrm{~m} \mathrm{~s}^{-1}$ in the morning of 1 May (Fig. 4).

In the Desert and desert steppe regions (the Gobi) of the country in spring season, Normalized Difference Vegetation Index (NDVI) is less than 0.24 [3, 25]. As a result of less and scarce vegetation condition around the site (Fig. 2), zero plane displacement $(d)$ in Eq. 3 was neglected and the vertical eddy diffusivity $\left(K_{z}\right)$ was calculated at $10 \mathrm{~m}$ height using Eq. 3. $\mathrm{K}_{\mathrm{z}}$ ranged from 0.327 to $5.347 \mathrm{~m}^{2} \mathrm{~s}^{-1}$ during IOP and it was higher in day time and lower in night time. The Monin-Obukhov length scale $(L)$ is estimated by Eq.4. We described the surface layer stability conditions based on the MoninObukhov length scale (L), for each 10 minute period. For large absolute values of $\mathrm{L}$, the atmosphere approaches a near-neutral state (i.e. turbulence is mechanically generated) $[26,27]$. The large absolute values of $\mathrm{L}$ were estimated in night time. Instead of the Monin-Obukhov length scale, a dimensionless length scale is chosen in order to show stability, which is defined as $\zeta=\mathrm{z} / \mathrm{L}$; and here $\mathrm{z}$ is $8 \mathrm{~m}$ level where the measurements are taken. The $\zeta=z / L$ is zero for neutral stratification, and positive (negative) for stable (unstable) stratifications. In our case, $\zeta$ was negative in 12:00-20:40 LST (day time) on 30 April, and positive from 20:50 on 30 April to 7:50 LST (night time) on 1 May 2016. Likewise, $\zeta$ was negative from 8:00 to 21:20 LST in day time on 1 May 2016. According to L and $\zeta$, daytime periods were primarily classified as unstable, while nighttime periods were as stable.

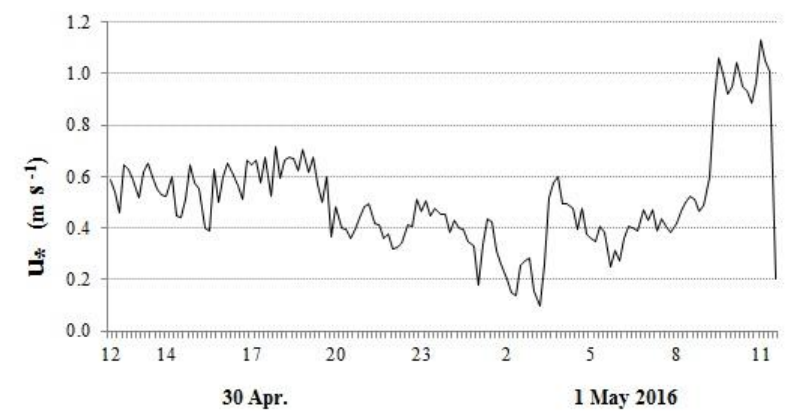

Figure 4. Friction velocity $\left(\boldsymbol{u}_{*}\right)$ at the Nomgon site during IOP.

\subsection{Vertical dust flux estimation}

In horizontally-homogeneous boundary layers, flow properties vary only in the vertical direction [6]. We suppose the dust-concentration field is horizontally homogeneous. Vertical dust flux $(F)$ for $\mathrm{PM}_{10}$ dust concentration is estimated with the gradient method using Eq. 2 using data from the gradient measurements of $\mathrm{PM}_{10}$ at 0.9 and $2.95 \mathrm{~m}$ levels.

Vertical dust flux $(F)$ for $\mathrm{PM}_{10}$ dust concentration 
varied from 0.01538 to $47.0105 \mu \mathrm{g} \mathrm{m}^{-2} \mathrm{~s}^{-1}$, especially, it rose from 7.2062 to $47.0105 \mu \mathrm{g} \mathrm{m}^{-2} \mathrm{~s}^{-1}$ at 9:2011:30 LST on 1 May 2016 (Fig. 5). According to values of the parameters from the best-fitting, when $n=3$ in Eq. 5, coefficient of determination $\left(R^{2}\right)$ was 0.567563 and regression coefficient, $a$, was as 0.0084395 . The relationship equation between friction velocity $\left(u_{*}\right)$ and vertical dust flux $(F)$ was defined as: $F=0.0084395 \cdot u_{*}^{3}$

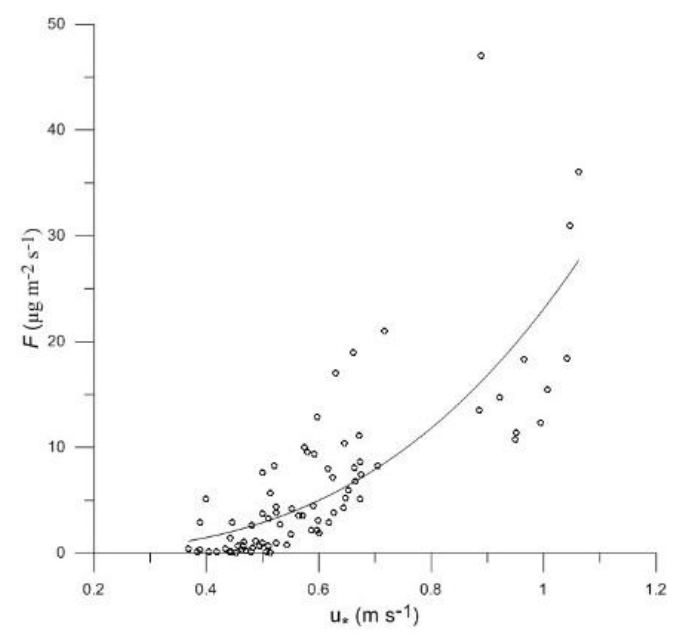

Figure 5. Relationship between vertical dust flux $(F)$ and friction velocity $\left(u_{*}\right)$.

\section{Conclusions}

The main results of this study are summarized as follows:

The dust event occurred from 30 April to 1 May 2016 in association with passage of a low-pressure system and its atmospheric frontal activities over Mongolia. Data analysis of this study showed that air and soil were dry during the dust storm period. Relative humidity of air and soil moisture at $5 \mathrm{~cm}$ depth was $13.4-21.0 \%$ and $7.7-8.8 \%$, respectively. Moreover, wind speed and $\mathrm{PM}_{10}$ dust concentration reached to $15-17 \mathrm{~m} \mathrm{~s}^{-1}$ and $88-338 \mu \mathrm{g} \mathrm{m}^{-3}$, respectively.

The vertical dust emission flux is estimated by using the gradient method with dust concentrations measured at two levels and vertical eddy diffusivity evaluated by the turbulent fluxes at $8-\mathrm{m}$ height during the IOP. Moreover, the estimation was calculated for the unstable stratification. The vertical dust emission flux is closely related to the friction velocity $\left(u_{*}\right)$. In the morning of 1 May 2016, estimated vertical dust flux $(F)$ for $\mathrm{PM}_{10}$ dust concentration rose from 7.2062 to $47.0105 \mu \mathrm{g} \mathrm{m}^{-2} \mathrm{~s}^{-1}$ and evaluated friction velocity $\left(u_{*}\right)$ was high as $0.88-1.06 \mathrm{~m} \mathrm{~s}^{-1}$ in that time. Our estimated vertical dust flux values were comparable with other study results by $[21,28,29]$.

\section{References}

1. D. Jugder, M. Shinoda, N. Sugimoto, I. Matsui, M. Nishikawa, S.U. Park, Y.S. Chun and M.S. Park, Glob. Planet. Change 78, 14-22 (2011)
2. D. Jugder, N. Sugimoto, M. Shinoda, I. Matsui, M. Nishikawa, Atmos. Env. 54, 231-241 (2012)

3. D. Jugder, M. Shinoda, R. Kimura, A. Batbold, D. Amarjargal, Aeolian Res. 14, 3-13 (2014)

4. D. Jugder, M. Shinoda, SOLA 7A, 029-031 (2011)

5. L. Natsagdorj, D. Jugder, Y.S. Chung, Atmos. Env. 37, 1401-1411 (2003)

6. Y. Shao, Physics and Modelling of Wind Erosion, 37, (2008)

7. A. Bartzokas, P. Kassomenos, Indoor Built Environ 0, $1-6$ (2003)

8. D.A. Gillette, I.H. Blifford, Jr., C.R. Fenster, Appl. Meteorol. 11, 977-987 (1972)

9. M.S. Sow, S. C. Alfaro, J. L. Rajot, B. Marticorena, Atmos. Chem. Phys. 9, 3881-3891 (2009)

10. H.S. Zhang, H. Zhu, Y. Peng, L. Kang, J. Chen, S.U. Park, Acta Meteorol. Sin. 22(2), 239-247 (2008)

11. F. Guarnieri, F. Calastrini, C. Busillo, M. Pasqui, S. Becagli, F. Lucarelli, G. Calzolai, S. Nava, R. Udisti, Biogeosciences Discuss. 8, 7313-7338 (2011)

12. B. Marticorena, G. Bergametti, J. Geophys. Res. 100, 16415-16430 (1995)

13. R.B. Stull, An introduction to boundary layer meteorology (1988)

14. B. Sharratt, G.L. Feng, Soil Till. Res. 105, 236-241, (2009)

15. D.A. Gillette, Trans. Am. Soc. Agric. Eng. 890- 897, (1977)

16. D.A. Gillette, R. Passi, J. Geophys. Res. 93, 1423314242 (1988)

17. W.G. Nickling, J.A. Gillies, Emission of fine-grained particulates from desert soils, (In: Leinen, M., Sarntheim, M. (Eds.), Paleoclimatology and Paleometeorology: Modern and Past Patterns of Glob. Atmos. Transport.), (1989)

18. I. Tegen, I. Fung, J. Geophys. Res. 100, 1870718726 (1995)

19. I. Uno, H. Amano, S. Emori, K. Kinoshita, I. Matsui, N. Sugimoto, J. Geophys. Res. 106 (D16), 1833118344 (2001)

20. M.S. Park, S.U. Park, Y.S. Chun, Sci. Total Environ. 412-413, 265-277 (2011)

21. S.U. Park, J.W. Ju, I.H. Lee, S.J. Joo, Atmos. Env. 140, 420-431 (2016)

22. K. Saxton, D. Chandler, L. Stetler, B. Lamb, C. Claiborn, B.H. Lee, Am. Soc. Agric. Eng. 43 (3), 623630 (2000)

23. R. Briant, L. Menut, G. Siour, C. Prigent, Geosci. Model Dev. Discuss. 7, 3441-3480 (2014)

24. Review of agrometeorology for April 2016, Information and Research Institute of Meteorology, Hydrology and Environment, Mongolia (2016)

25. R. Kimura, M. Shinoda, Geomorphology. 114, 319 325 (2010)

26. A.Kuparinen, G. Katul, R.Nathan, F.M.Schurr, Proc. R. Soc. B 276, 3081-3087 (2009)

27. S.Monin, A. M. Obukhov, Tr. Akad. Nauk SSSR Geophiz. Inst. 24(151), 163-187 (1954)

28. J.A.Gillies, W.G. Nickling, Atmos. Env. 30, 7, 10811090 (1996)

29. X. Li, H. Zhang, Atmos. Env. 61, 56-65 (2012) 